University of Wollongong

Research Online

Faculty of Engineering and Information

Faculty of Engineering and Information

Sciences - Papers: Part A

Sciences

$1-1-2015$

Osmotic dilution for sustainable greenwall irrigation by liquid fertilizer:

Performance and implications

\author{
Ming Xie \\ University of Wollongong, mx504@uowmail.edu.au \\ Mingxin Zheng \\ University of Wollongong \\ Paul Cooper \\ University of Wollongong, pcooper@uow.edu.au \\ William E. Price \\ University of Wollongong, wprice@uow.edu.au \\ Long D. Nghiem \\ University of Wollongong, longn@uow.edu.au
}

See next page for additional authors

Follow this and additional works at: https://ro.uow.edu.au/eispapers

Part of the Engineering Commons, and the Science and Technology Studies Commons

Research Online is the open access institutional repository for the University of Wollongong. For further information contact the UOW Library: research-pubs@uow.edu.au 


\title{
Osmotic dilution for sustainable greenwall irrigation by liquid fertilizer: Performance and implications
}

\begin{abstract}
A novel osmotic dilution process using commercial liquid fertilizer for greenwall irrigation was evaluated. In this process, clean water was extracted from raw sewage by forward osmosis (FO) using a wellbalanced, all-purpose commercial liquid fertilizer as draw solution. The diluted liquid fertilizer can then be used for direct sustainable greenwall irrigation. Our results show that the presence of organic matter in the liquid fertilizer draw solution did not compromise FO membrane performance. No discernible changes in water flux and key membrane transport parameters (pure water permeability coefficient, $A$, and salt $(\mathrm{NaCl})$ permeability coefficient, $\mathrm{B}$ ) were observed when the organic matter concentration in the draw solution was increased to $2000 \mathrm{mg} / \mathrm{L}$. Parameters influencing the osmotic dilution process were examined in terms of reverse salt flux, liquid fertilizer concentration, cross-flow rate, and feed and liquid fertilizer draw solution temperatures. The reverse flux of phosphate was much lower compared to those of ammonium and potassium as the reverse flux of these solutes were proportionally related to their hydrated radii. Cross-flow rate had no discernible impact on either water flux or reverse nutrient transport. Water and reverse nutrient fluxes increased markedly with increasing temperature, driven by higher water and solute diffusivities. More than $80 \%$ water recovery was achieved by osmotic dilution using raw sewage feed. Water production was stable and not affected by deposition of organic matter on the membrane surface. By contrast, reverse nutrient diffusion was hindered due to enhanced steric hindrance. Results reported here have significant environmental implications. Extracting clean water from raw sewage by commercial liquid fertilizers harnesses unique FO mass transfer phenomena and balances greenwall nutrient requirement, thereby sustaining the greenwall irrigation process.
\end{abstract}

\section{Keywords}

performance, fertilizer, osmotic, implications, dilution, irrigation, liquid, sustainable, greenwall

\section{Disciplines}

Engineering | Science and Technology Studies

\section{Publication Details}

Xie, M., Zheng, M., Cooper, P., Price, W. E., Nghiem, L. D. \& Elimelech, M. (2015). Osmotic dilution for sustainable greenwall irrigation by liquid fertilizer: Performance and implications. Journal of Membrane Science, 494 32-38.

\section{Authors}

Ming Xie, Mingxin Zheng, Paul Cooper, William E. Price, Long D. Nghiem, and Menachem Elimelech 


\section{Osmotic Dilution for Sustainable Greenwall Irrigation by Liquid Fertilizer: Performance and Implications}

\section{Journal of Membrane Science}

Revised: July 6, 2015

Ming Xie ${ }^{1,4}$, Mingxin Zheng ${ }^{1,2}$, Paul Cooper ${ }^{2}$, William E. Price ${ }^{3}$, Long D. Nghiem $1,2, *$, Menachem Elimelech ${ }^{4}$

${ }^{1}$ Strategic Water Infrastructure Laboratory, School of Civil, Mining, and Environmental Engineering, University of Wollongong, Wollongong, NSW 2522, Australia

${ }^{2}$ Sustainable Buildings Research Centre (SBRC), University of Wollongong, Wollongong, NSW 2522, Australia

${ }^{3}$ Strategic Water Infrastructure Laboratory, School of Chemistry, University of Wollongong, Wollongong, NSW 2522, Australia

${ }^{4}$ Department of Chemical and Environmental Engineering, Yale University, New Haven, CT 06520-8286, United States

\footnotetext{
* Corresponding author: Long Duc Nghiem, Email: longn@uow.edu.au; Ph +61 242214590
} 


\begin{abstract}
A novel osmotic dilution process using commercial liquid fertilizer for greenwall irrigation was evaluated. In this process, clean water was extracted from raw sewage by forward osmosis (FO) using a well-balanced, all-purpose commercial liquid fertilizer as a draw solution. The diluted liquid fertilizer can then be used for direct sustainable greenwall irrigation. Our results show that the presence of organic matter in the liquid fertilizer draw solution did not compromise FO membrane performance. No discernible changes in water flux and key membrane transport parameters (pure water permeability coefficient, $A$, and salt $(\mathrm{NaCl})$ permeability coefficient $B$ ) were observed when the organic matter concentration in the draw solution was increased to $2,000 \mathrm{mg} / \mathrm{L}$. Parameters influencing the osmotic dilution process were examined in terms of reverse salt flux, liquid fertilizer concentration, cross-flow rate, and feed and liquid fertilizer draw solution temperatures. The reverse flux of phosphate was much lower compared to those of ammonium and potassium as the reverse flux of these solutes were proportionally related to their hydrated radii. Cross-flow rate had no discernible impact on either water flux or reverse nutrient transport. Water and reverse nutrient fluxes increased markedly with increasing temperature, driven by higher water and solute diffusivities. More than $80 \%$ water recovery was achieved by osmotic dilution using raw sewage feed. Water production was stable and was not affected by deposition of organic matter on the membrane surface. By contrast, reverse nutrient diffusion was hindered due to enhanced steric hindrance. Results reported here have significant environmental implications. Extracting clean water from raw sewage by commercial liquid fertilizers harnesses unique FO mass transfer phenomena and balances greenwall nutrient requirement, thereby sustaining the greenwall irrigation process.
\end{abstract}

Keywords: Osmotic dilution; greenwall irrigation; commercial liquid fertilizer; water production; reverse nutrient transport. 


\section{Introduction}

Greenwalls have increasingly become an important component of modern urban infrastructure to improve building sustainability, amenity, and aesthetic appearance $[1,2]$. Outdoor greenwalls can rely to some extent on natural precipitation as a source of water for irrigation [3]. However, in arid and semi-arid regions, supplementary irrigation is also required, depending on the type of plants and green wall materials used [4]. For indoor greenwalls, the volume of irrigation water used is much larger, ranging from 6 to $9 \mathrm{~L} / \mathrm{m}^{2}$-day [5]. A greenwall is usually equipped with an automatic irrigation system, with water flowing from the top internally through the greenwall materials by gravity to a reservoir at the base of the structure where it is circulated back to the top by pumping.

Osmotic dilution, or an osmotically driven membrane process, could be a promising platform for greenwall irrigation. Using osmotic dilution, clean water can be extracted from an impaired source, such as raw sewage or greywater, under an osmotic pressure gradient generated by a draw solution through a forward osmosis (FO) membrane. The FO membrane is made of either cellulose acetate or polyamide reinforced by a porous support layer [6-8]. Osmotic dilution has demonstrated its robustness and effectiveness for treating low quality, impaired waters, such as digested sludge [9-12], sewage [13-17], and produced water from oil and gas exploration [18-20].

Results from the literature suggest that osmotic dilution could also potentially be used to extract water from raw sewage or greywater for greenwall irrigation. The diluted fertilizer draw solution can be used directly for irrigation without the energy intensive draw solution recovery process [21]. Furthermore, in a vertical greenwall, the circulation of water is also part of the irrigation process, thus, the additional energy consumption for osmotic dilution is negligible.

Previous FO fertigation studies using specific inorganic salts (e.g., $\mathrm{KNO}_{3}, \mathrm{NH}_{4} \mathrm{NO}_{3}$, $\mathrm{KCl}$ ) have limitations when the diluted draw solution does not have all nutrients, as a balanced nutrient ratio is required for plant growth [22, 23]. In addition, without necessary supplements, fertilizer-based draw solutions obtained from osmotic dilution can adversely affect the infiltration capacity of soil [24]. As a result, a well-balanced, all-purpose liquid fertilizer is proposed, for the first time, as a draw solution in osmotic dilution for greenwall irrigation. The liquid fertilizer constitutes all essential macronutrients with a balanced ratio, 
and is further fortified with humic substances to improve soil condition, thereby facilitating plant nutrient uptake.

One challenge associated with utilising an all-purpose liquid fertilizer draw solution in osmotic dilution is the presence of high concentration humic acid. Although a previous study has demonstrated that the presence of organic matter at low concentration in seawater and seawater brine did not affect FO performance [25], the concentration of humic substances in an all-purpose liquid fertilizer is several orders of magnitudes higher than what has been examined. The impact of high concentration of humic substances on the FO membrane process is largely unknown and brings uncertainties to the osmotic dilution process. Furthermore, to date, the use of osmotic dilution for greenwall irrigation has not been evaluated. No previous studies have addressed the use of commercial liquid fertilizers, which contain all nutrients necessary for plant growth as well as high concentration of membrane foulants.

Osmotic dilution can be readily integrated into an existing greenwall irrigation system. In such a system, as noted above, a diluted liquid fertilizer can be used directly as the draw solution and irrigated water can be circulated to the top of the greenwall structure and through the osmotic dilution process at the same time. Utilising greywater as the source water could substantially improve the irrigation efficiency, particularly during dry periods [5]. In addition, a draw solution utilising a commercial liquid fertilizer has significant advantages over single [23] or blended [22] synthetic (or inorganic) fertilizers, such as balanced macroand micro-nutrients, and essential soil conditioner (e.g. humic acid) to facilitate nutrient uptake.

To develop an osmotic dilution system for greenwall irrigation, it is necessary to assess a range of basic performance parameters. For examples, fluctuations in the greywater temperature, caused by activities such as hot shower and dish washing, could have an impact on the osmotic dilution irrigation process. It is also necessary to evaluate the effect of a low circulation flow comparable to that used in an existing greenwall irrigation system on water flux through the FO membrane. In addition, commercially available FO membranes are not perfect and loss of draw solutes is expected due to their diffusion from the draw solution (high concentration) to the feed (low concentration). In the context of an osmotic dilution system for greenwall irrigation, these draw solutes (i.e. potassium, phosphate, and ammonia) are also key ingredients of the liquid fertilizer. Thus, it is essential to evaluate these draw solute losses when using a commercially available membrane. Lastly, unlike its synthetic 
counterpart, most liquid fertilizers are seaweed or fish extract and contain a significant amount of humic-like materials. Thus, it is important to assess if these humic like materials could cause membrane fouling during osmotic dilution.

The aim of this study is to examine and optimize the osmotic dilution process using a commercial liquid fertilizer draw solution in terms of water production and reverse nutrient diffusion. Key membrane transport parameters were characterized and compared to facilitate the application of such a draw solution in an osmotic dilution system. Important operating parameters, including liquid fertilizer concentration, cross-flow rate, and feed and liquid fertilizer draw solution temperatures, were optimized and practically related to greenwall irrigation. Raw sewage was processed by osmotic dilution using commercial liquid fertilizer where water and reverse nutrient fluxes (i.e. $\mathrm{K}^{+}, \mathrm{NH}_{4}{ }^{+}$and $\mathrm{PO}_{4}{ }^{3-}$ ) were quantified to shed light on the efficiency of osmotic dilution in greenwall irrigation.

\section{Materials and methods}

\subsection{Forward osmosis membrane and liquid fertilizer}

A commercially available FO membrane (Hydration Technology Innovations, Oregon, USA) was used in this study. The FO membrane comprised a cellulose triacetate (CTA) layer with an embedded woven supporting mesh. Further details about this FO membrane are available elsewhere [6, 26]. Liquid fertilizer was obtained from a horticulture supplier (Powerfeed, VIC, Australia) and used as the draw solution. This is an organically based fish extract fortified with additional nutrients and blended with liquid humus to produce an allpurpose liquid fertilizer. The liquid fertilizer draw solution contains essential nutrients (i.e. $\mathrm{K}^{+}, \mathrm{NH}_{4}^{+}$, and $\mathrm{PO}_{4}{ }^{3-}$ ) and organic matter. Key characteristics of the liquid fertilizer are summarized in Table 1. The liquid fertilizer is slightly alkaline $(\mathrm{pH}=10.3)$. However, the membrane was used in FO mode (i.e., the draw solution was in contact with the membrane support layer) and we did not observe any abnormal increase in water or reverse solute flux which may indicate membrane degradation in this study. 
Table 1: Key characteristics for liquid fertilizer as draw solution (average \pm standard deviation from duplicate sample)

\begin{tabular}{cc}
\hline Parameter & Value \\
\hline $\mathrm{pH}(-)$ & $10.3 \pm 0.2$ \\
Conductivity $(\mathrm{mS} / \mathrm{cm})$ & $104.8 \pm 0.5$ \\
Osmotic pressure (as NaCl) (bar) & $82.5 \pm 2.5$ \\
$\mathrm{NH}_{4}{ }^{+}(\mathrm{g} / \mathrm{L})$ & $138.5 \pm 3.8$ \\
$\mathrm{PO}_{4}{ }^{3-}(\mathrm{g} / \mathrm{L})$ & $16.4 \pm 1.5$ \\
$\mathrm{~K}^{+}(\mathrm{g} / \mathrm{L})$ & $92.8 \pm 2.2$ \\
Humic acid $(\mathrm{g} / \mathrm{L})$ & $2.6 \pm 0.2$ \\
\hline
\end{tabular}

\subsection{Osmotic dilution setup}

Osmotic dilution experiments were conducted using a closed-loop bench-scale FO membrane system (Supplementary Data, Figure S1). The membrane cell was made of acrylic plastic and had channel dimensions of $13 \mathrm{~cm}$ long, $9.5 \mathrm{~cm}$ wide, and $0.2 \mathrm{~cm}$ deep. The total effective membrane area was $123.5 \mathrm{~cm}^{2}$. Two variable speed gear pumps (Micropump, Vancouver, WA) were used to circulate the feed and draw solutions. Flow rates of the feed and draw solutions were monitored using rotameters. The draw solution reservoir was placed on a digital balance (Mettler Toledo Inc., Hightstown, NJ) and weight changes were recorded by a computer to calculate the permeate water flux. Further details of this FO membrane system are available elsewhere [27].

\subsection{Experimental protocol}

Prior to the osmotic dilution experiments, the performance of the FO membrane was evaluated by either $0.5 \mathrm{M} \mathrm{NaCl}$ (denoted as "clean") or $0.5 \mathrm{M} \mathrm{NaCl}$ with 2,000 mg/L humic acid (denoted as "humic acid draw") draw solution. The humic acid used here (SigmaAldrich, St. Louis, MO), representing organic matter, constitutes a major component in commercial liquid fertilizer (Table 1). The FO membrane water flux was continuously monitored and compared under these two types of draw solutions. At the conclusion of each experiment, the pure water permeability coefficient of the active layer $(A)$ and the salt $(\mathrm{NaCl})$ permeability coefficient of the active layer $(B)$ of both membranes (i.e. clean and humic acid draw) were determined following the protocol previously described by Cath et al. [28]. Briefly, the membrane $A$ and $B$ values were determined using a reverse osmosis (RO) crossflow filtration system (Figure S2, Supplementary data). The membrane $A$ value was measured 
at a pressure of 10 bar using deionised water. $\mathrm{NaCl}$ was then added to the feed solution to determine the $B$ value. The RO system was stabilised for two hours before recording permeate water flux with $2000 \mathrm{mg} / \mathrm{L} \mathrm{NaCl}$ solution, $J_{w}^{\mathrm{NaCl}}$, and taking feed and permeate samples to determine the observed $\mathrm{NaCl}$ rejection, $R_{o}$. Membrane $A$ value was calculated by dividing the pure water permeate flux $\left(J_{w}^{R O}\right)$ by the applied hydraulic pressure, $\Delta P$ :

$$
A=J_{w}^{R O} / \Delta P
$$

The observed salt $(\mathrm{NaCl})$ rejection, $R_{o}$, was calculated from the difference between the bulk feed $\left(c_{b}\right)$ and permeate $\left(c_{p}\right)$ salt concentrations, $R_{o}=1-c_{p} / c_{b}$, and then the membrane $B$ value was determined from:

$$
B=J_{w}^{N a C l}\left(\frac{1-R_{o}}{R_{o}}\right) \exp \left(-\frac{J_{w}^{N a C l}}{k_{f}}\right)
$$

where $k_{f}$ is the mass transfer coefficient for the cross-flow of RO membrane cell [29].

The influence of key operating parameters (i.e. liquid fertilizer concentration, crossflow rate, and feed and draw solution temperature) on water flux was evaluated for optimising the osmotic dilution process. The initial volumes of the feed and draw liquid fertilizer were 4 and $1 \mathrm{~L}$, respectively. A new FO membrane sample was used for each experiment, which was concluded when $1 \mathrm{~L}$ water had permeated through the FO membrane (i.e. $25 \%$ water recovery). Water flux was recorded continuously and the average water flux during the permeation of $1 \mathrm{~L}$ water was reported. Concentrations of the draw liquid fertilizer (v/v) were adjusted by deionized water dilution, designated as 100, 50, and 25\%, respectively. Two cross-flow rates, 0.5 and $1 \mathrm{~L} / \mathrm{min}$ (corresponding to cross-flow velocities of 4.5 and $9 \mathrm{~cm} / \mathrm{s}$ ), were selected for both feed and liquid fertilizer draw to represent either slow or fast greenwall irrigation scenarios. Both feed and liquid fertilizer draw temperatures were adjusted to 5,25 , or $45^{\circ} \mathrm{C}$ to simulate the possible household wastewater temperatures ranging from unheated water in the winter to wastewater from the dishwasher or a hot shower.

Reverse nutrient $\left(\mathrm{K}^{+}, \mathrm{NH}_{4}{ }^{+}\right.$, and $\left.\mathrm{PO}_{4}{ }^{3-}\right)$ fluxes were quantified by analysing their concentrations in the feed solution at the conclusion of each experiment. Samples $(50 \mathrm{~mL})$ from the feed solution were taken at the beginning and after $1 \mathrm{~L}$ water had permeated through the FO membrane for nutrient analysis. 
Either a foulant-free synthetic solution (clean feed) or raw sewage (sewage feed) was processed continuously by osmotic dilution using commercial liquid fertilizer draw solution. Initial volumes for feed and draw solutions were 4 and $1 \mathrm{~L}$, respectively. Water flux was recorded continuously, while reverse nutrient flux (i.e. $\mathrm{K}^{+}, \mathrm{NH}_{4}{ }^{+}$, and $\mathrm{PO}_{4}{ }^{3-}$ ) was determined at the conclusion of each experiment. Key characteristics of raw sewage are summarized in Table 2.

Table 2: Key characteristics of raw sewage (average \pm standard deviation from duplicate sample)

\begin{tabular}{cc}
\hline Parameter & Value \\
\hline $\mathrm{pH}(-)$ & $7.13 \pm 0.2$ \\
Conductivity $(\mu \mathrm{S} / \mathrm{cm})$ & $1079 \pm 5$ \\
Total suspended solids $(\mathrm{mg} / \mathrm{L})$ & $122 \pm 3$ \\
$\mathrm{NH}_{4}{ }^{+}(\mathrm{mg} / \mathrm{L})$ & $38.5 \pm 5.8$ \\
$\mathrm{PO}_{4}{ }^{3-}(\mathrm{mg} / \mathrm{L})$ & $5.4 \pm 0.5$ \\
$\mathrm{~K}^{+}(\mathrm{mg} / \mathrm{L})$ & $18.2 \pm 1.1$ \\
$\mathrm{TOC}^{(\mathrm{mg} / \mathrm{L})}$ & $72.6 \pm 1.2$ \\
\hline
\end{tabular}

\subsection{Analytical methods}

Ammonium $\left(\mathrm{NH}_{4}{ }^{+}\right)$and orthophosphate $\left(\mathrm{PO}_{4}{ }^{3-}\right)$ concentrations were determined using a Flow Injection Analysis system (QuikChem 8500, Lachat, Loveland, CO). Potassium $\left(\mathrm{K}^{+}\right)$ concentration was determined by inductively coupled plasma mass spectrometry (ICP-MS) (Agilent 7500cs, Agilent Technologies, Wilmington, DE) using a method described elsewhere [30]. Solution $\mathrm{pH}$ and electrical conductivity were measured using an Orion 4-Star Plus pH/conductivity meter (Thermo Scientific, Waltham, MA).

\section{Results and discussion}

\subsection{Effect of humic substances in the draw solution on FO performance}

The presence of humic substances at very high concentration in the liquid fertilizer draw solution did not affect the FO process (Figure 1). There was no discernible difference in FO water flux between clean $0.5 \mathrm{M} \mathrm{NaCl}$ or $0.5 \mathrm{M} \mathrm{NaCl}$ with $2,000 \mathrm{mg} / \mathrm{L}$ humic acid draw solution (Figure 1A), indicating that the presence of humic acid in the membrane support layer did not induce observable fouling. The key membrane transport parameters (pure water permeability coefficient, $A$, salt $(\mathrm{NaCl})$ permeability coefficient, $B)$ of a clean membrane and 
a membrane with the support layer exposed to $2,000 \mathrm{mg} / \mathrm{L}$ of humic acid were almost identical (Figure 1B). The unimpaired FO membrane performance at high humic acid concentration could be attributed to the permeate flow characteristic where forward water permeation (i.e., from the feed facing the active layer to the draw solution facing the support layer) prevents the accumulation of humic acid on the membrane support layer [25].
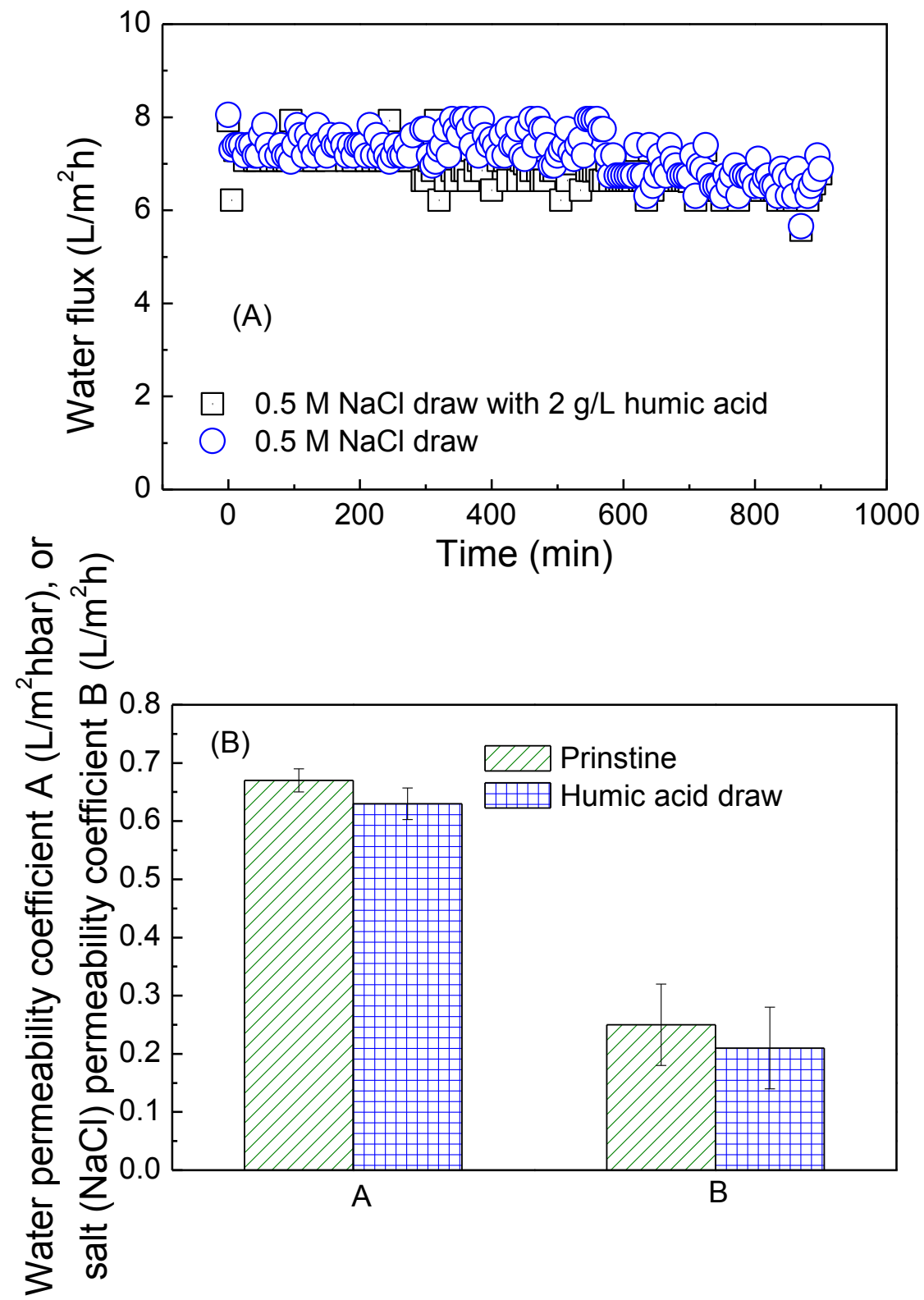

Figure 1: Comparison of (A) FO water flux using either $0.5 \mathrm{M} \mathrm{NaCl}$ or $0.5 \mathrm{M} \mathrm{NaCl}$ with 2 $\mathrm{g} / \mathrm{L}$ humic acid draw and (B) membrane transport parameters ( $A, B$ values) of pristine and humic acid draw membranes. Experimental conditions were: feed solution contains background electrolyte ( $20 \mathrm{mM} \mathrm{NaCl}$ and $1 \mathrm{mM} \mathrm{NaCHO}_{3}$ ); either $0.5 \mathrm{M} \mathrm{NaCl}$ or $0.5 \mathrm{M} \mathrm{NaCl}$ with $2 \mathrm{~g} / \mathrm{L}$ humic acid was draw solution; cross-flow rates of both feed and draw solutions were $1 \mathrm{~L} / \mathrm{min}$ (corresponding to cross-flow velocity of $9 \mathrm{~cm} / \mathrm{s}$ ); temperatures of feed and 
draw solutions were $25 \pm 0.1{ }^{\circ} \mathrm{C}$. Error bars represent standard deviation from duplication measurements of two membrane samples.

The stable FO membrane performance is a key for unlocking the potential for utilising commercially available liquid fertilizer as draw solution in osmotic dilution for greenwall irrigation. The well-balanced liquid fertilizer offers more advantages in comparison to synthetic fertilizer [23], such as promoting plant root mass and improving soil quality and structure [31], which are beneficial to greenwall irrigation.

\subsection{Optimizing osmotic dilution for greenwall irrigation}

\subsubsection{Liquid fertilizer concentration}

Liquid fertilizer draw solution provides the driving force for osmotic dilution. As expected, the water flux increased proportionally with increasing liquid fertilizer concentration (Figure 2A). On the other hand, reverse solute diffusion, which is a unique mass transfer phenomenon in FO, led to nutrient loss from the liquid fertilizer draw solution (Figure 2B). The reverse permeation of nutrients was in the following order: ammonium > potassium > phosphate, which was inversely correlated with the hydrated solute radii [32]: ammonium $(0.25 \mathrm{~nm})<$ potassium $(0.34 \mathrm{~nm})<$ phosphate $(0.49 \mathrm{~nm})$. This observation indicates that steric hindrance (size exclusion) played an important role in reverse nutrient transport [33-35]. Indeed, the reverse phosphate flux was one order of magnitude lower than those of ammonium and potassium. This much lower reverse phosphate diffusion was attributed to relatively larger phosphate hydrated radius of $0.49 \mathrm{~nm}$ than the estimated FO membrane average pore radius of $0.37 \mathrm{~nm}$ [27]. On the other hand, the phosphate solute, possessing a negative multivalent charge, was also subjected to stronger electrostatic repulsion, in comparison to potassium and ammonium. The much lower phosphate leakage is beneficial to nutrient uptake by greenwall plants. It is noteworthy that in a typical NPK fertilizer mixture, the phosphorus concentration is about 10 times less than nitrogen and potassium (Table 1). 


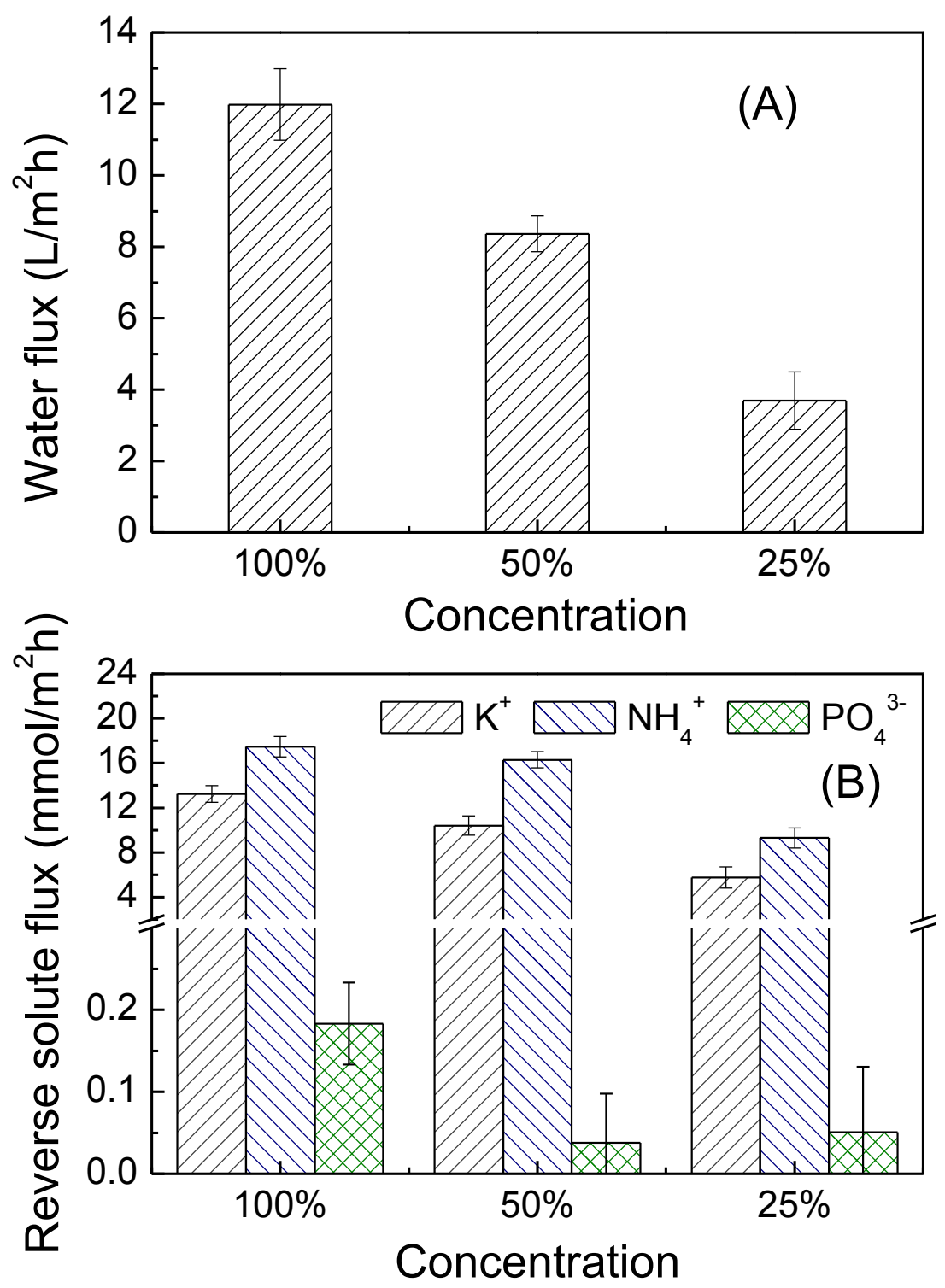

Figure 2: (A) Water and (B) reverse solute $\left(\mathrm{K}^{+}, \mathrm{NH}_{4}{ }^{+}, \mathrm{PO}_{4}{ }^{3-}\right)$ fluxes as a function of commercially available liquid fertilizer concentration. Experimental conditions were feed solution contained background electrolytes $\left(20 \mathrm{mM} \mathrm{NaCl}\right.$ and $1 \mathrm{mM} \mathrm{NaHCO}_{3}$ ). Draw solution was commercially available liquid fertilizer. Liquid fertilizer concentrations were $100 \%, 50 \%$, and $25 \%$, respectively. Cross-flow rate for both feed and draw solutions was 1 $\mathrm{L} / \mathrm{min}$ (corresponding to cross-flow velocity of $9 \mathrm{~cm} / \mathrm{s}$ ); temperatures of both feed and draw solutions were $25 \pm 0.1^{\circ} \mathrm{C}$. Error bars represent standard deviation of duplication experiment.

\subsubsection{Cross-flow rate}

Cross-flow rate exhibited negligible impact on osmotic dilution performance (Figure 3). Water flux only decreased marginally when the cross-flow rate was reduced by half to 0.5 $\mathrm{L} / \mathrm{min}$ (corresponding to cross-flow velocity of $4.5 \mathrm{~cm} / \mathrm{s}$ ) (Figure $3 \mathrm{~A}$ ). In addition, there were 
no significant differences in reverse nutrient transport under the two cross-flow rates used (Figure 3B). Similar insignificant variation in mass transfer was also reported by Kim et al. [36] who examined boron transport through an FO membrane under three different crossflow velocities ranging from 10 to $30 \mathrm{~cm} / \mathrm{s}$.

In a typical greenwall fertigation process, the water flow rate ranges from 0.1 to $1 \mathrm{~L} / \mathrm{min}$ [37, 38], depending on the plant species and greenwall soil substrate. As a result, results reported here indicate that the low circulation flow rate typically used in the greenwall irrigation system would not have a significant impact on water flux of osmotic dilution process.
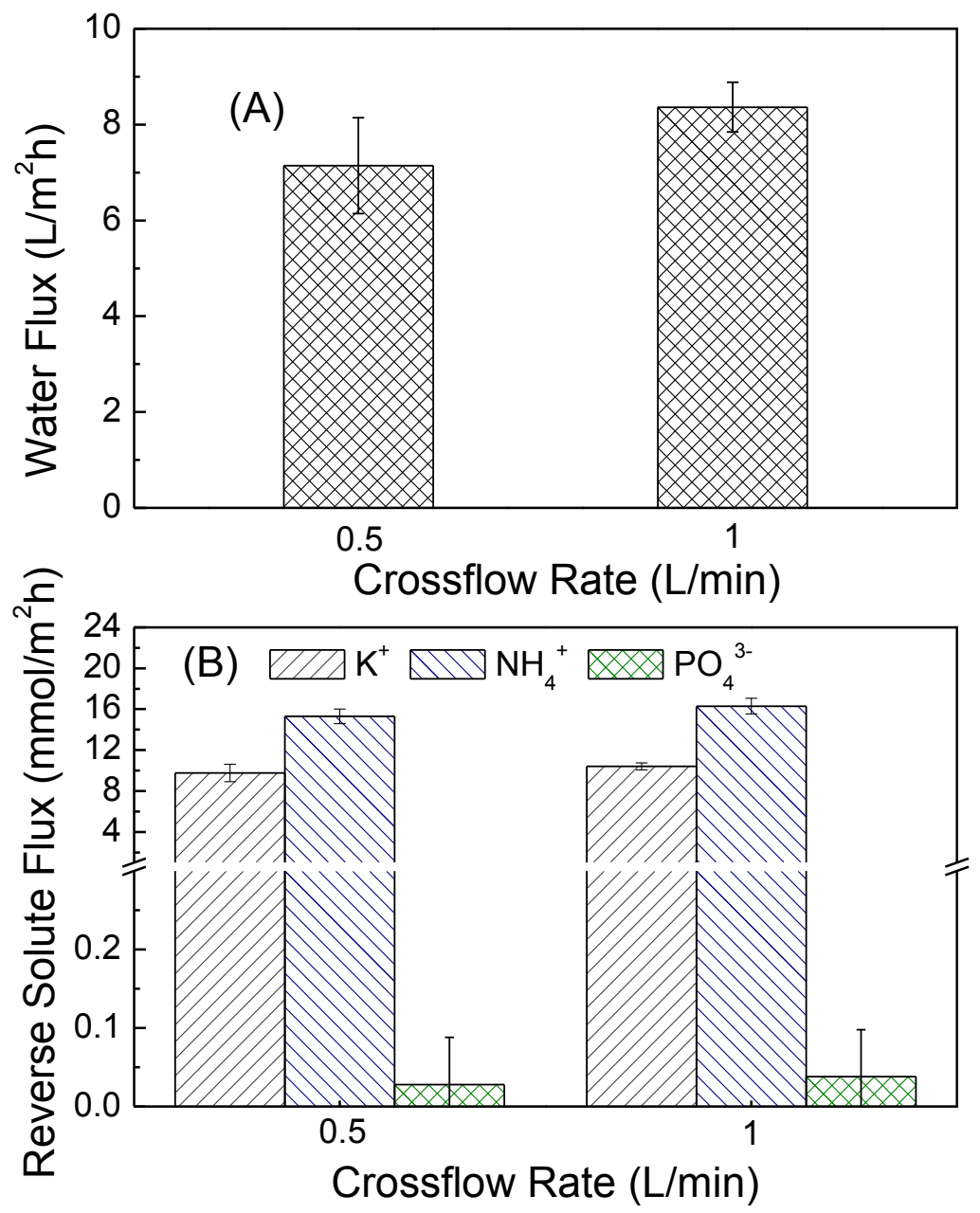

Figure 3: (A) Water and (B) reverse solute $\left(\mathrm{K}^{+}, \mathrm{NH}_{4}{ }^{+}, \mathrm{PO}_{4}{ }^{3-}\right)$ fluxes as a function of crossflow rate. Experimental conditions : Feed solution contained background electrolytes $(20 \mathrm{mM}$ $\mathrm{NaCl}$ and $1 \mathrm{mM} \mathrm{NaHCO}_{3}$ ). Draw solution was a commercially available liquid fertilizer diluted to $50 \%$ by deionized water. Cross-flow rates for both feed and draw solutions were 0.5 and $1 \mathrm{~L} / \mathrm{min}$, respectively (corresponding to cross-flow velocities of 4.5 and $9 \mathrm{~cm} / \mathrm{s}$, 
respectively); temperatures of both feed and draw solutions were $25 \pm 0.1{ }^{\circ} \mathrm{C}$. Error bars represent standard deviation of duplication experiment.

\subsubsection{Feed and draw solution temperature}

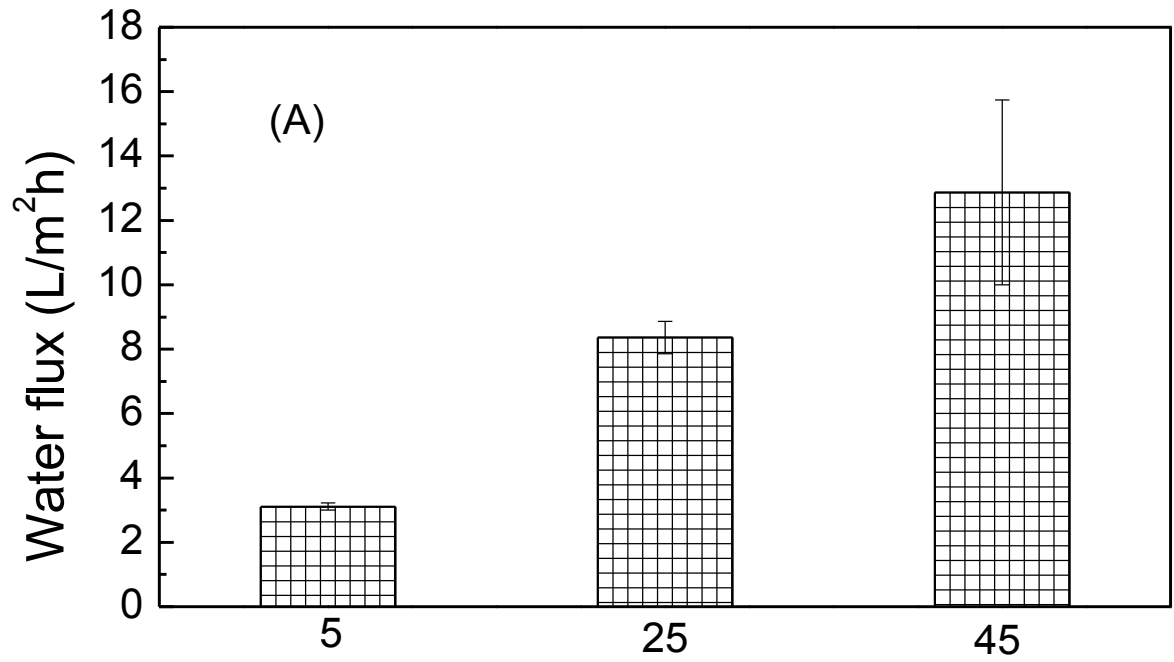

Feed and draw solution temperature $\left({ }^{\circ} \mathrm{C}\right)$

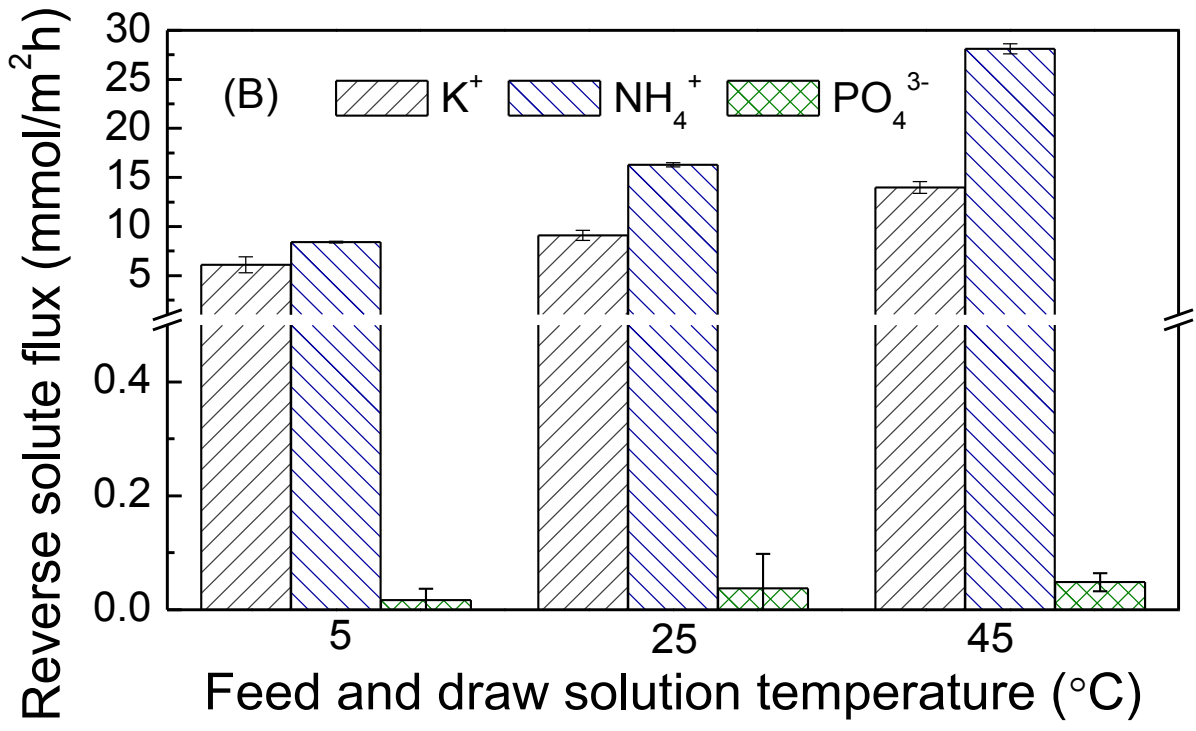

Figure 4: (A) Water and (B) reverse solute $\left(\mathrm{K}^{+}, \mathrm{NH}_{4}{ }^{+}, \mathrm{PO}_{4}{ }^{3-}\right)$ fluxes as a function of feed and draw solution temperature. Experimental conditions were feed solution contained background electrolytes $(20 \mathrm{mM} \mathrm{NaCl} \text { and } 1 \mathrm{mM} \mathrm{NaHCO})_{3}$. Draw solution was commercially available liquid fertilizer diluted to $50 \%$ by deionized water. Cross-flow rates for both feed and draw solutions was $1 \mathrm{~L} / \mathrm{min}$ (corresponding to cross-flow velocities of 9 $\mathrm{cm} / \mathrm{s}$, respectively); temperatures of both feed and draw solutions were $5 \pm 0.1,25 \pm 0.1$, and $45 \pm 0.1^{\circ} \mathrm{C}$, respectively. Error bars represent standard deviation of duplication experiment. 
Temperature exerted a marked impact on both water and reverse nutrient transport in osmotic dilution (Figure 4). Water flux increased four-fold as feed and liquid fertilizer draw temperatures increased from 5 to $45{ }^{\circ} \mathrm{C}$ (Figure 4A). The enhanced water permeation was mainly because of higher water diffusivity at an elevated temperature, thereby improving water flux $[39,40]$. At the same time, a similar trend was also observed in reverse nutrient diffusion (Figure 4B). This result was consistent with our previous study where the reverse $\mathrm{NaCl}$ flux increased as feed and draw solution temperatures increased from 20 to $40{ }^{\circ} \mathrm{C}$ [39]. The concomitant increase in water and reverse nutrient transport indicates that variation in the feed source water temperature should be taken into account in designing an osmotic dilution system for greenwall irrigation.

\subsubsection{Implications for greenwall irrigation}

The aforementioned three key operating parameters (liquid fertilizer concentration, cross-flow rate, and feed and draw solution temperatures) have significant implications for greenwall irrigation. Specifically, liquid fertilizer concentration and cross-flow rate are related to the energy and chemical operating costs for greenwall irrigation. In addition, feed source water could be household greywater, with temperatures varying seasonally (from summer to winter) and spatially (from hot shower to cool tap water).

\subsection{Water production by osmotic dilution for greenwall irrigation}

Osmotic dilution extracted 3,250 mL product water from either clean or sewage feed, reaching $80 \%$ water recovery (Figure 5A). Water flux decreased gradually because of continuous concentration of feed solution and dilution of liquid fertilizer draw solution (i.e. decrease in driving force). More importantly, there was only a marginal change in water flux extracted from clean feed water compared to a sewage feed, indicating the low membrane fouling propensity in osmotic dilution [41]. A detailed examination of the membrane after the FO experiment revealed a brownish cake layer on the membrane active surface when sewage feed was used (data not shown). This cake layer was formed at a relatively low initial water flux (about $10 \mathrm{~L} / \mathrm{m}^{2} \mathrm{~h}$ ), with loose and fluid-like characteristics, thereby not impacting water flux [42].

Although the water flux was relatively stable with both feeds, the cake layer formed with the sewage led to a pronounced decrease in reverse nutrient diffusion compared to the clean feed (Figure 5B). We surmise that foulant deposition facilitated the formation of a thin fouling layer which reduced reverse solute diffusion. Similar reduction in reverse solute 
transport was reported in our previous study where humic acid fouling was examined using $\mathrm{NaCl}$ draw solution [43].

The losses of potassium (312 mg), ammonium (120 mg) and phosphate $(2.38 \mathrm{mg})$ per square meter per hour (Figure 5B) due to reverse diffusion were three orders of magnitude lower than their concentrations in the liquid fertilizer (Table 1). In other words, for each square meter of membrane over one hour, changes in the fertilizer composition were less than $0.1 \%$. It is also noteworthy that the reverse flux of phosphate, which has the smallest concentration in liquid fertilizer (Table 1$)$, is negligible $\left(2.38 \mathrm{mg} / \mathrm{m}^{2} \mathrm{~h}\right)$.
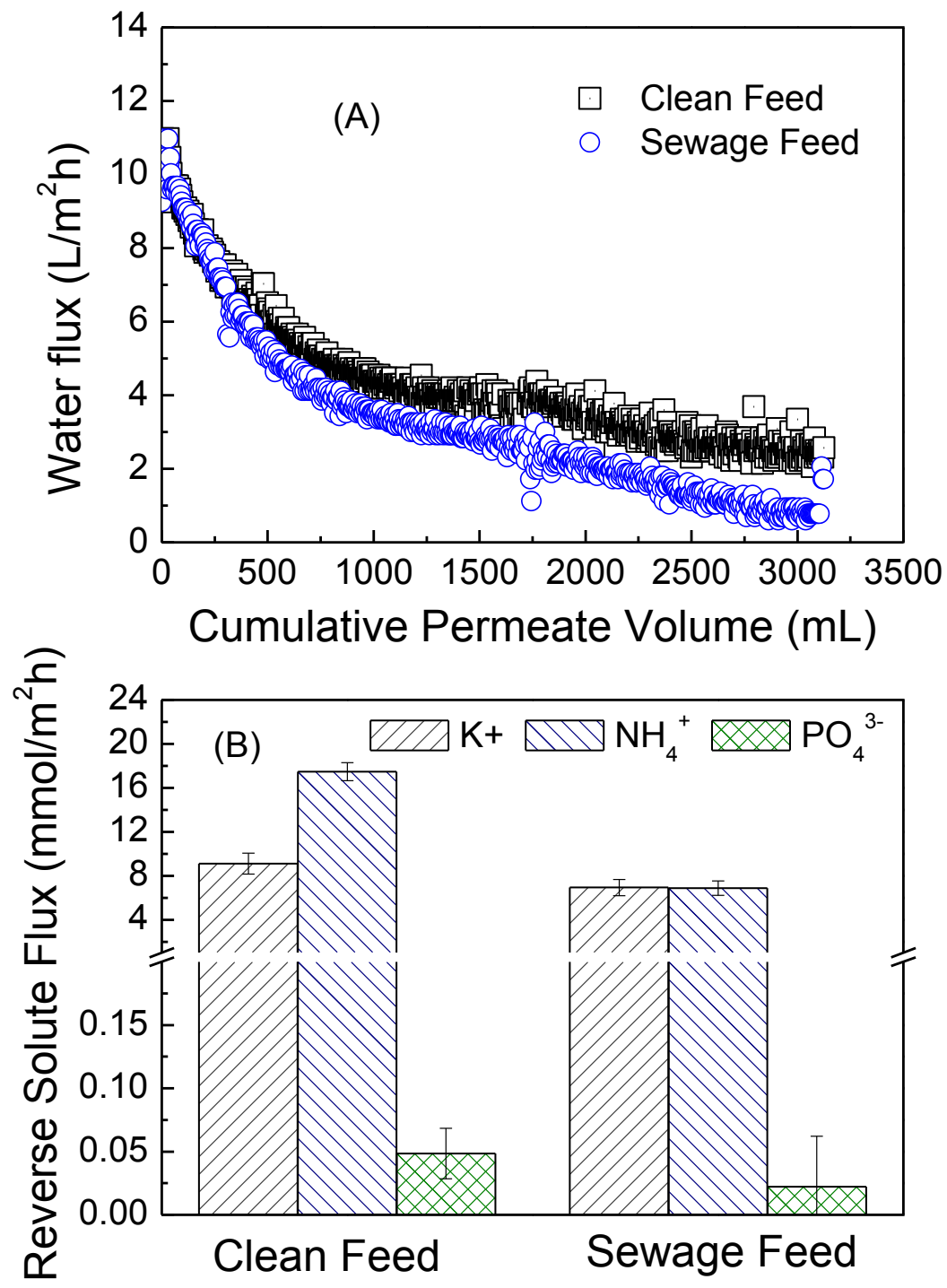

Figure 5: Comparison of (A) water production and (B) reverse solute $\left(\mathrm{K}^{+}, \mathrm{NH}_{4}{ }^{+}, \mathrm{PO}_{4}{ }^{3-}\right)$ fluxes using liquid fertilizer draw solution from either clean or sewage feed (Table 2). Experimental conditions: feed solution was either background electrolyte $(20 \mathrm{mM} \mathrm{NaCl}$ and 1 $\mathrm{mM} \mathrm{NaCHO}_{3}$ ) or raw sewage (without pre-treatment). Draw solution was commercially 
available liquid fertilizer (dilution to $50 \%$ of the initial concentration). Cross-flow rate for both feed and draw solutions was $1 \mathrm{~L} / \mathrm{min}$ (corresponding to cross-flow velocity of $9 \mathrm{~cm} / \mathrm{s}$ ). Temperatures for both feed and draw solutions were $25 \pm 0.1{ }^{\circ} \mathrm{C}$. The system was operated for 72 hours, extracting 3,250 $\mathrm{mL}$ product water into liquid fertilizer draw solution. Error bars represent standard deviation of duplication experiment.

The osmotic dilution process proposed here also has significant environmental implications for greenwall irrigation applications. The osmotic dilution fully takes advantage of the FO process without draw solution re-concentration, achieving low energy consumption. Indeed, the simultaneous water extraction and liquid fertilizer dilution offer a viable approach for greywater reclamation within residential buildings as well as a sustainable strategy for greenwall irrigation, thereby reducing the water and energy footprint of buildings.

\section{Conclusion}

Results reported here demonstrate the successful implementation of a novel osmotic dilution process using commercial liquid fertilizers for greenwall irrigation. Presence of organic matter in the liquid fertilizer draw solution did not compromise FO membrane performance. The efficiency of the osmotic dilution process was evaluated in terms of liquid fertilizer concentration, cross-flow rate, and feed and liquid fertilizer draw solution temperatures. The reverse salt flux of phosphate, potassium and ammonium increased in line with decreasing hydrated solute radii. In particular, phosphate had the smallest reverse flux of $0.05 \mathrm{mmol} / \mathrm{m}^{2} \mathrm{~h}$. The cross-flow rate did not significantly impact either the water flux or reverse nutrient transport. Water and reverse nutrient fluxes increased markedly with increasing temperature, which was driven by higher water and solute diffusivities. More than $80 \%$ water recovery was achieved by osmotic dilution using either a foulant-free synthetic solution or raw sewage as the feed. Water production was stable and was not affected by the deposition of organic matter on the membrane surface. By contrast, reverse nutrient diffusion was hindered with raw sewage feed due to enhanced solute retention by the thin fouling layer.

\section{Acknowledgements}

The University of Wollongong is thanked for the provision of a doctoral scholarship to Ming Xie. A top-up scholarship to Ming Xie from the Global Challenges Program (University of Wollongong) is also gratefully acknowledged. Mingxin Zheng would like to thank the Sustainable Buildings Research Centre for a summer scholarship. 


\section{References}

[1] S.R. Gaffin, C. Rosenzweig, A.Y.Y. Kong, Adapting to climate change through urban green infrastructure, Nature Clim. Change, 2 (2012) 704-704.

[2] A.M. Hunter, N.S.G. Williams, J.P. Rayner, L. Aye, D. Hes, S.J. Livesley, Quantifying the thermal performance of green façades: A critical review, Ecological Engineering, 63 (2014) 102-113.

[3] M.A. Benedict, E.T. MacMahon, Green infrastructure: Smart conservation for the 21st century, Renewable Resources Journal, 20 (2002) 12-17.

[4] M. Razzaghmanesh, S. Beecham, F. Kazemi, The growth and survival of plants in urban green roofs in a dry climate, Science of The Total Environment, 476-477 (2014) 288-297.

[5] O. Schweitzer, E. Erell, Evaluation of the energy performance and irrigation requirements of extensive green roofs in a water-scarce Mediterranean climate, Energy and Buildings, 68, Part A (2014) 25-32.

[6] T.Y. Cath, A.E. Childress, M. Elimelech, Forward osmosis: Principles, applications, and recent developments, Journal of Membrane Science, 281 (2006) 70-87.

[7] S. Zhao, L. Zou, C.Y. Tang, D. Mulcahy, Recent developments in forward osmosis: Opportunities and challenges, Journal of Membrane Science, 396 (2012) 1-21.

[8] R. Wang, L. Shi, C.Y. Tang, S. Chou, C. Qiu, A.G. Fane, Characterization of novel forward osmosis hollow fiber membranes, Journal of Membrane Science, 355 (2010) 158167.

[9] R.W. Holloway, A.E. Childress, K.E. Dennett, T.Y. Cath, Forward osmosis for concentration of anaerobic digester centrate, Water Research, 41 (2007) 4005-4014.

[10] N.C. Nguyen, S.-S. Chen, H.-Y. Yang, N.T. Hau, Application of forward osmosis on dewatering of high nutrient sludge, Bioresource Technology, 132 (2013) 224-229.

[11] M. Xie, L.D. Nghiem, W.E. Price, M. Elimelech, Toward Resource Recovery from Wastewater: Extraction of Phosphorus from Digested Sludge Using a Hybrid Forward Osmosis-Membrane Distillation Process, Environmental Science \& Technology Letters, (2014).

[12] N.T. Hau, S.-S. Chen, N.C. Nguyen, K.Z. Huang, H.H. Ngo, W. Guo, Exploration of EDTA sodium salt as novel draw solution in forward osmosis process for dewatering of high nutrient sludge, Journal of Membrane Science, 455 (2014) 305-311.

[13] E.R. Cornelissen, D. Harmsen, K.F. de Korte, C.J. Ruiken, J.-J. Qin, H. Oo, L.P. Wessels, Membrane fouling and process performance of forward osmosis membranes on activated sludge, Journal of Membrane Science, 319 (2008) 158-168.

[14] T.Y. Cath, S. Gormly, E.G. Beaudry, M.T. Flynn, V.D. Adams, A.E. Childress, Membrane contactor processes for wastewater reclamation in space: Part I. Direct osmotic concentration as pretreatment for reverse osmosis, Journal of Membrane Science, 257 (2005) 85-98.

[15] K. Lutchmiah, E.R. Cornelissen, D.J.H. Harmsen, J.W. Post, K. Lampi, H. Ramaekers, L.C. Rietveld, K. Roest, Water recovery from sewage using forward osmosis, Water Science \& Technology, 64 (2011) 1443-1449. 
[16] M. Xie, L.D. Nghiem, W.E. Price, M. Elimelech, A Forward Osmosis-Membrane Distillation Hybrid Process for Direct Sewer Mining: System Performance and Limitations, Environmental Science \& Technology, 47 (2013) 13486-13493.

[17] W.C.L. Lay, Q. Zhang, J. Zhang, D. McDougald, C. Tang, R. Wang, Y. Liu, A.G. Fane, Effect of Pharmaceuticals on the Performance of a Novel Osmotic Membrane Bioreactor (OMBR), Separation Science and Technology, 47 (2011) 543-554.

[18] R.L. McGinnis, N.T. Hancock, M.S. Nowosielski-Slepowron, G.D. McGurgan, Pilot demonstration of the $\mathrm{NH} 3 / \mathrm{CO} 2$ forward osmosis desalination process on high salinity brines, Desalination, 312 (2013) 67-74.

[19] D.L. Shaffer, L.H. Arias Chavez, M. Ben-Sasson, S. Romero-Vargas Castrillón, N.Y. Yip, M. Elimelech, Desalination and Reuse of High-Salinity Shale Gas Produced Water: Drivers, Technologies, and Future Directions, Environmental Science \& Technology, 47 (2013) 9569-9583.

[20] L. Xue-Mei, Z. Baolong, W. Zhouwei, X. Ming, S. Jianfeng, L.D. Nghiem, H. Tao, Y. Chi, L. Chunxia, C. Gang, Water reclamation from shale gas drilling flow-back fluid using a novel forward osmosis-vacuum membrane distillation hybrid system, Water Science \& Technology, 69 (2014) 1036-1044.

[21] L.A. Hoover, W.A. Phillip, A. Tiraferri, N.Y. Yip, M. Elimelech, Forward with Osmosis: Emerging Applications for Greater Sustainability, Environmental Science \& Technology, 45 (2011) 9824-9830.

[22] S. Phuntsho, H.K. Shon, T. Majeed, I. El Saliby, S. Vigneswaran, J. Kandasamy, S. Hong, S. Lee, Blended Fertilizers as Draw Solutions for Fertilizer-Drawn Forward Osmosis Desalination, Environmental Science \& Technology, 46 (2012) 4567-4575.

[23] S. Phuntsho, H.K. Shon, S. Hong, S. Lee, S. Vigneswaran, A novel low energy fertilizer driven forward osmosis desalination for direct fertigation: Evaluating the performance of fertilizer draw solutions, Journal of Membrane Science, 375 (2011) 172-181.

[24] G.A. Bezborodov, D.K. Shadmanov, R.T. Mirhashimov, T. Yuldashev, A.S. Qureshi, A.D. Noble, M. Qadir, Mulching and water quality effects on soil salinity and sodicity dynamics and cotton productivity in Central Asia, Agriculture, Ecosystems \& Environment, 138 (2010) 95-102.

[25] C. Boo, M. Elimelech, S. Hong, Fouling control in a forward osmosis process integrating seawater desalination and wastewater reclamation, Journal of Membrane Science, 444 (2013) 148-156.

[26] J.R. McCutcheon, M. Elimelech, Influence of membrane support layer hydrophobicity on water flux in osmotically driven membrane processes, Journal of Membrane Science, 318 (2008) 458-466.

[27] M. Xie, L.D. Nghiem, W.E. Price, M. Elimelech, Comparison of the removal of hydrophobic trace organic contaminants by forward osmosis and reverse osmosis, Water Research, 46 (2012) 2683-2692.

[28] T.Y. Cath, M. Elimelech, J.R. McCutcheon, R.L. McGinnis, A. Achilli, D. Anastasio, A.R. Brady, A.E. Childress, I.V. Farr, N.T. Hancock, J. Lampi, L.D. Nghiem, M. Xie, N.Y. Yip, Standard Methodology for Evaluating Membrane Performance in Osmotically Driven Membrane Processes, Desalination, 312 (2013) 31-38. 
[29] E.M.V. Hoek, A.S. Kim, M. Elimelech, Influence of crossflow membrane filter geometry and shear rate on colloidal fouling in reverse osmosis and nanofiltration separations, Environ. Eng. Sci., 19 (2002) 357.

[30] K.L. Tu, A.R. Chivas, L.D. Nghiem, Enhanced boron rejection by NF/RO membranes by complexation with polyols: Measurement and mechanisms, Desalination, 310 (2013) 115121.

[31] L. Canfora, E. Malusà, L. Salvati, G. Renzi, M. Petrarulo, A. Benedetti, Short-term impact of two liquid organic fertilizers on Solanum lycopersicum L. rhizosphere Eubacteria and Archaea diversity, Applied Soil Ecology, 88 (2015) 50-59.

[32] E.R. Nightingale, Phenomenological Theory of Ion Solvation. Effective Radii of Hydrated Ions, The Journal of Physical Chemistry, 63 (1959) 1381-1387.

[33] A.A. Alturki, J.A. McDonald, S.J. Khan, W.E. Price, L.D. Nghiem, M. Elimelech, Removal of trace organic contaminants by the forward osmosis process, Separation and Purification Technology, 103 (2013) 258-266.

[34] R. Valladares Linares, V. Yangali-Quintanilla, Z. Li, G. Amy, Rejection of micropollutants by clean and fouled forward osmosis membrane, Water Research, 45 (2011) 6737-6744.

[35] M. Xie, W.E. Price, L.D. Nghiem, Rejection of pharmaceutically active compounds by forward osmosis: Role of solution $\mathrm{pH}$ and membrane orientation, Separation and Purification Technology, 93 (2012) 107-114.

[36] C. Kim, S. Lee, H.K. Shon, M. Elimelech, S. Hong, Boron transport in forward osmosis: Measurements, mechanisms, and comparison with reverse osmosis, Journal of Membrane Science, 419-420 (2012) 42-48.

[37] Harmanto, V.M. Salokhe, M.S. Babel, H.J. Tantau, Water requirement of drip irrigated tomatoes grown in greenhouse in tropical environment, Agricultural Water Management, 71 (2005) 225-242.

[38] A. Palla, I. Gnecco, L.G. Lanza, Unsaturated 2D modelling of subsurface water flow in the coarse-grained porous matrix of a green roof, Journal of Hydrology, 379 (2009) 193-204.

[39] M. Xie, W.E. Price, L.D. Nghiem, M. Elimelech, Effects of feed and draw solution temperature and transmembrane temperature difference on the rejection of trace organic contaminants by forward osmosis, Journal of Membrane Science, 438 (2013) 57-64.

[40] S.-J. You, X.-H. Wang, M. Zhong, Y.-J. Zhong, C. Yu, N.-Q. Ren, Temperature as a factor affecting transmembrane water flux in forward osmosis: Steady-state modeling and experimental validation, Chemical Engineering Journal, 198-199 (2012) 52-60.

[41] B. Mi, M. Elimelech, Organic fouling of forward osmosis membranes: Fouling reversibility and cleaning without chemical reagents, Journal of Membrane Science, 348 (2010) 337-345.

[42] M. Xie, L.D. Nghiem, W.E. Price, M. Elimelech, Impact of organic and colloidal fouling on trace organic contaminant rejection by forward osmosis: Role of initial permeate flux, Desalination, 336 (2014) 146-152.

[43] M. Xie, L.D. Nghiem, W.E. Price, M. Elimelech, Impact of humic acid fouling on membrane performance and transport of pharmaceutically active compounds in forward osmosis, Water Research, 47 (2013) 4567-4575. 